\title{
Characterization and Classification of Soils on Quartzite-Schistose Landscape in Tropical Ecosystem of Goa-in a Topo-sequence
}

\author{
D. S. Mohekar ${ }^{1 *}$, S. K. Singh $^{2}$, S. Chattaraj ${ }^{1}$, V. Ramamurthy ${ }^{3}$ and R. Srivastava ${ }^{1}$ \\ ${ }^{1}$ ICAR-National Bureau of Soil Survey and Land Use Planning, \\ Amravati road, Nagpur, Maharashtra, India \\ ${ }^{2}$ ICAR-Central Coastal Agricultural Research Institute, Goa, India \\ ${ }^{3}$ ICAR-National Bureau of Soil Survey and Land Use Planning, \\ Regional Centre, Bangalore, Karnataka, India \\ *Corresponding author
}

\section{A B S T R A C T}

\begin{tabular}{|l|}
\hline Ke y w o r d s \\
$\begin{array}{l}\text { Soil } \\
\text { characterization, } \\
\text { Classification, } \\
\text { Landscape }\end{array}$ \\
\hline Article Info \\
\hline $\begin{array}{l}\text { Accepted: } \\
\text { 14 May } 2020 \\
\text { Available Online: } \\
\text { 10 June } 2020\end{array}$ \\
\hline
\end{tabular}

Nine typical pedons representing major quartzite-schistose landscape in tropical ecosystem of Goa viz., high hills, restricted summits, low hills, inter-hilly valley and narrow valley under varying land use were studied for their morphological characteristics, physical and chemical properties, soil genesis and taxonomy. The soils were slightly to moderately acidic in reaction, very shallow to very deep. Texture of the soils varied from gravelly sandy clay loam to gravelly clay on the hills and sandy clay loam to clay in valley soils. The clay content, bulk density, AWC, organic carbon, cation exchange capacity, base saturation and exchangeable hydrogen and aluminium in the soils were ranged from 34.3 to 46.8 per cent, 1.30 to $1.48 \mathrm{Mg} \mathrm{m}^{-3}$, 1.4 to $14.0 \mathrm{~cm} \mathrm{~m}^{-1}, 0.4$ to 4.0 per cent, 5.5 to $18.4 \mathrm{cmol}(\mathrm{p}+) \mathrm{kg}^{-1}, 19.3$ to 63.5 per cent, 0.02 to $0.19 \mathrm{cmol}(\mathrm{p}+) \mathrm{kg}^{-1}$ and 0.0 to $0.48 \mathrm{cmol}(\mathrm{p}+) \mathrm{kg}^{-1}$ respectively. The soils had isohyperthermic temperature regime and ustic soil moisture regime. The soils were grouped under three soil orders viz., Entisols, Inceptisols and Alfisols and further classified into four families viz., Lithic Ustorthents, Lithic Haplustepts, Dystric Haplustepts, Typic Haplustalfs.

\section{Introduction}

Sustainable management of land resources is essential for food security, maintenance of environment and general well-being of the people. Management of finite soil resources in agro-ecological regions is highly essential not only to increase the yield of different crops but also to sustain productivity.
Indiscriminate use of resources couple with lack of management has, however, led to degradation echoing the concern of planners, researchers and farmers alike (Sharma 2006) ${ }^{(15)}$.

Soil resource inventory through characterization of the resources provides an insight into the potentials and limitation of 
soils. (Manchanda et al., 2002) ${ }^{(9)}$. Soils are considered integral part of the landscape and thus characteristics are largely governed by the landforms on which they have developed (Sharma et al., 1999) ${ }^{(16)}$. A landform comprises a geomorphological unit and is largely defined by its surface form and location in the landscape. The importance of soil-landform relationship in soil survey and mapping, provide a fair understanding of variability across the landscape needed for sustainable agricultural planning (Murthy, 1982) $)^{(11)}$.

Systematic study of morphology and taxonomy of soils gives an idea about nature and type of soils, their constraint, potential capabilities and suitability for various uses (Sehgal, 1996) ${ }^{(13)}$.The state of Goa belongs to AER 19 defined as Western Ghats and Coastal plains; Hot humid and per humid ecoregion having variety of landforms and soils. Characterization, classification and evaluation of soils for different land uses are the first milestone to develop sustainable and eco-friendly land use models. Sporadic information available on characterization and classification of soils in Goa (Govindarajan et al., $1974^{(5)}$, Singh et al., 1998 $\left.{ }^{(17)}\right)$, but very few information is available especially on soil genesis, characterization and classification pertaining to soils of quartzite-schistose landform in the state of Goa. Keeping this in view, the present study was attempted.

\section{Materials and Methods}

The state of Goa is located between $14^{\circ} 53^{\prime}$ $47^{\prime \prime}$ to $15^{\circ} 47^{\prime} 59^{\prime \prime} \mathrm{N}$ latitudes and $73^{\circ} 40^{\prime} 54^{\prime \prime}$ to $74^{\circ} 20^{\prime} 11^{\prime \prime} \mathrm{E}$ longitudes with an area of $3702 \mathrm{~km}^{2}$ (Fig. 1). It accounts for about 1 per cent of the total geographical area of the country. Mandovi, Zuari, Terekhol, Chapora and Betul are the main river in the state. Goa, being in the tropical zone and near the Arabian Sea, has a warm and humid climate for most of the year with mean annual temperature of $27.8^{\circ} \mathrm{C}$. The mean maximum and minimum temperature are recorded in the month of May $\left(30.2^{\circ} \mathrm{C}\right)$ and January $\left(26.4^{\circ} \mathrm{C}\right)$. The soil temperature regime is hence isohyperthermic (Sehgal and Mandal, 1994) ${ }^{(14)}$. The south west monsoon yields a total annual precipitation of about $2910.5 \mathrm{~mm}$ from June to October. The maximum rainfall is in the month of June $(828.8 \mathrm{~mm})$. The relative humidity, in general varies from 89 to 67 per cent. The state of Goa belongs to AER 19 defined as Western Ghats and Coastal plains; Hot humid and per humid ecoregion with red \& lateritic and Alluvium derived soils with LGP of 210 to 270 days or more (Mandal et. al., 2016) ${ }^{(10)}$.

This has further classified into 19.2 and 19.3 AESR (unpublished data).At the physiography level Goa state is the part of Ghats which were divided into two subphysiographic units namely Central Sahyadri/Western Ghats $(\mathrm{Hw})$ and the west coasts (Pw). Central Sahyadri/Western Ghats was divided into two broad landscape 1) granite, and granite-gneiss, and 2) Quartziteschistose landscape. Konkan Coast was divided into 1) Dissected hilly laterite and 2) Fluvio-littoral landscape. Basalt was considered as broad landform in South Deccan Plateau (Harindranath et al., 1999) ${ }^{(6)}$.The natural vegetation consists of trees, shrubs, hurbs, climbers, sedges and grasses like neem (Azadiracta indica), babul (Acacia spp.), bamboo (Bobax alba), khair (Acacia catechu), lantana (Lantana camara), mango (Mangifera indica), teak (Tectona grandis),jack fruit (Artocarpus heterophyllus) etc.

High resolution remote sensing dataIRS-P6 LISS-IV of 5.8 meter resolution, Cartosat-1 DEM of 10 meter resolution (year: 2014-15) and public domain data (i.e. online Google earth imagery) were used for the study. 
The land resource inventory was conducted using base map on 1:10000 scale. A detailed traverse of the area was made to identify the major landforms. Nine representative pedons (Table 1) from each landform in a toposequence dominantly occurring on quartziteschistose landscape in the state have been selected for the study (Figure 1). The soils of Pedon 1 and 2 were representative of high hill. Pedon 3 and 4 were representative of restricted summit, Pedon 5 and 6 were representative of low hill, Pedon 7 and 8 were representative of inter-hilly basin/valley and Pedon 9 were representative of narrow valley. The soils were studied for their various morphological properties (Table 2) as per USDA Soil Survey Manual (Soil Survey Staff, 2000) ${ }^{(19)}$. Horizon wise soil samples were collected and analysed for important physical and chemical properties using standard procedures (Jackson 1973) ${ }^{(7)}$. The soils were classified taxonomically (Soil Survey Staff, 2006) ${ }^{(20)}$.

\section{Results and Discussion}

\section{Morphological characteristics of soils}

It is apparent from the data present in table 1, 2 and figure 2. The soils on the restricted summits and low hills were very shallow to moderately shallow, severely to moderately eroded, well to excessively drained. Whereas, soils on high hills and in the intervening and narrow valleys were moderately deep to very deep, moderately eroded, well drained. Mean thickness of surface and sub-surface horizons were 15.8 and $63.9 \mathrm{~cm}$. Soils on high hills, low hills and restricted summits had redder hue ranging from 2.5 to $5 \mathrm{YR}$, whereas, soils in the inter-hilly valley and narrow valley had grayish to brown hue ranging from 7.5 YR to 10 YR. High rainfall and high temperature with well to excessive drainage were favourable for desilication and fertilization. This is probably one of the reasons for redder hue at the hills. The dark matrix colour was due to the presence of high organic matter content in the surface horizons (Tripathi et al., $2006)^{(22)}$. However, availability of comparatively high moisture on the lower topography may be the reason for grayish to brown hue at the valleys (James et al., $1996^{(8)}$; Singh et al., $\left.1998^{(17)}\right)$. Probably regular agronomy for rice restrained the expression of such relationship.

Soil texture varied from gravelly sandy clay loam to gravelly clay at the surface on the hills and it was clay loam to clay in the soils of inter-hilly valley whereas sandy clay loam in the soils of narrow valley. These were accompanied by clayey and occasionally gravelly clayey texture in the sub-surface. This textural variation might be due to differences in composition of parent material, topography, in-situ weathering and translocation of clay by eluviation and age of soils (Geetha Sireesha and Naidu 2013) ${ }^{(18)}$. Fine to medium, weak sub-angular blocky structure was noted dominantly at the surface across the landform. Erosion and destructive influence of cultural practices were the reasons for smaller size and weaker soil structure at the surface. In the sub-surface, dominantly coarse strong sub-angular blocky structure breaking to medium moderate subangular blocky structure. This could be ascribed to the higher content of free iron oxides as cementing agent for striking expression of soil structure in the sub-soils. Few, fine, distinct yellowish to reddish brown mottles between the depths of 40 to $78 \mathrm{~cm}$ were prominently appeared in the soils of narrow valleys This is the indicative of presence of water for some times in the soil profile. Movement of clays in the soil profile was established by locating the presence of argillans in the soil profile. Patchy thin clay cutans were very common at the lower part of the soils associated with the inter-hilly valleys. 


\section{Physical properties}

The physical characteristics of the soils is presented in table 3 and discussed in this section. Mean sand content was 38.8 and 33.1 per cent at the surface and in the sub-surface varying in the confidence interval of 33.7 to 43.9 per cent and 28.6 to 37.6 per cent, respectively. Mean sand content along the topography was decreased down the slope from high hills to intervening hilly valley. Mean silt content on the surface and subsurface, respectively was 23.5 and 23.3 per cent in the confidence interval of 20.3 to 26.7 and 20.5 to 26.1 per cent. Unlike sand content, silt content increased topographically down the slope. Mean clay content was 37.7 and 43.6 per cent at the surface and in the subsurface ranging in the confidence interval of 34.3 to 41.1 and 40.4 to 46.8 per cent, respectively. Unlike mean sand and silt content, distribution of clay does not follow the established relationship between soil texture and landforms from high hills to the inter-hilly valley. Sarkar et al., $(2001)^{(12)}$ and Garhwal et al., $(2013)^{(4)}$ have also reported higher clay content in soils occurring on gentler surfaces.

Mean bulk density was $1.4 \mathrm{Mg} \mathrm{m}^{-3}$ on the surface and in the subsurface varying in the confidence interval of 1.30 to $1.47 \mathrm{Mg} \mathrm{m}^{-3}$ at surface and 1.32 to $1.48 \mathrm{Mg} \mathrm{m}^{-3}$ at subsurface respectively. It was noted bulk density increases along the soil depth, might be due to the compaction of finer particles in deeper layers caused by the over-head weight of the surface layers (Thangasamy et al., 2005) ${ }^{(21)}$. The low bulk density in surface layers may be due to cultivation, high organic matter and biotic activities (Vara Prasad Rao et al., $2008)^{(23)}$. The AWC of different Pedon's varied from 1.4 to $14.0 \mathrm{~cm} \mathrm{~m}^{-1}$. These variations were due to the difference in depth, clay, silt, sand and organic carbon content. The low AWC in soils was due to high sand and less clay content as evident by negative correlation $\left(\mathrm{r}=-0.69^{* *}\right)$ between AWC and sand content. Study of AWC down the depth in the soil profile revealed that it was increased with increased clay content. Thus, AWC were the true reflections of the clay content in the soils of different landscapes and the topography explained the variations within the landform.

\section{Chemical properties}

In light of the data presented in table 4 it is noted that $\mathrm{pH}_{\mathrm{w}}$ was slightly to moderately acidic. The mean $\mathrm{pH}_{\mathrm{w}}$ was 5.8 in the confidence interval of5.7 to 5.9 at the surface and 5.9 in the confidence interval of 5.8 to 6.0 in the sub-surface. $Ә \mathrm{pH}$, the difference of $\mathrm{pH}_{\mathrm{KCl}}$ and $\mathrm{pH}_{\mathrm{w}}$ was -1.0 and -1.4 at the surface and in the sub-surface, respectively. Thus the potential acidity both on the surface and in the sub-surface was higher. The mean electrical conductivity (EC) was $0.07 \mathrm{dS} \mathrm{m}^{-1}$ at the surface and $0.03 \mathrm{dS} \mathrm{m}^{-1}$ in the subsurface varying from 0.02 to $0.23 \mathrm{dS} \mathrm{m}^{-1}$ and 0.02 to $0.11 \mathrm{dS} \mathrm{m}^{-1}$ respectively. The low EC in these soils was due to leaching of soluble salts by percolating water. SOC varied in the confidence interval of 0.5 to 4.0 at the surface and 0.4 to 2.3 per cent in the sub-surface with means of 2.9 and 1.7 per cent.

The higher values on the hills both at the surface and sub-surface were ascribed to the protected plantations. The high organic carbon in Goa reported by Anil Kumar et al., $(2011)^{(1)}$. Mean CEC was 13.2 and 12.3 $\mathrm{cmol}(\mathrm{p}+) \mathrm{kg}^{-1}$ at the surface and in subsurface soils with ranging from 5.5 to $18.4 \mathrm{cmol}(\mathrm{p}+)$ $\mathrm{kg}^{-1}$ at surface and 5.9 to $17.8 \mathrm{cmol}(\mathrm{p}+) \mathrm{kg}^{-1}$ in subsoil. It was high at the surface and decreased with the soil depth in general. The higher values of CEC in the upper horizons commensurate with amount of clay $\left(\mathrm{r}=0.85^{* *}\right)$ may be due to high organic matter content and soil reaction (Diwakar 2005) ${ }^{(2)}$. 
Exchangeable bases in the pedons were in the order of $\mathrm{Ca}^{2+}>\mathrm{Mg}^{2+}>\mathrm{Na}^{+}>\mathrm{K}^{+}$on the exchange complex with slightly reverse order in $\mathrm{Na}^{+}$ and $\mathrm{K}^{+}\left(\mathrm{K}^{+}>\mathrm{Na}^{+}\right)$in the soils of inter-hilly valley (Pedon 7 and 8 ) and $\mathrm{Ca}^{2+}$ being the dominant cation on the exchange complex. Mean base saturation was 34.3 per cent at the surface and below the surface soils it was 33.8 per cent. BS varies from 19.3 to 58.7 per cent at surface and 21.8 to 63.5 per cent in the subsurface. The values corroborate with the findings of Anil Kumar et al., $(2011)^{(1)}$ reported for the soils of Talaulim watershed of North Goa. No consistent relationship was noted between the base saturation and soil depth. The observations indicated that leaching of bases were the dominant process in the prevailing climatic conditions of Goa. Basically the base saturation is the true representation of lithology, however, topography influence the distribution of bases in the soil profile as witnessed at the intervening valley basin. Mean hydrogen and aluminium in the soils was nil to traces.

\section{Diagnostic horizons}

\section{Argillic horizon}

The sub-surface layer in the soils of pedon P7 and P8, (Table 3 ) were more than $15 \mathrm{~cm}$ thick and had clay content of more than 1.2 times higher from the overlying horizons together with the patchy thin argillans were characterized as argillic horizons (Table 2) Apart from the clay content, these were hold higher available water capacity. These horizons are indicated with the symbol of Bt.

\section{Cambic horizons}

Beside pedon P7 and P8 the sub-surface soils either with higher clay content or organic carbon or redder hue, darker chroma and value or signature of structural alterations in terms fine to medium, moderate sub-angular blocky structure than the underlying horizons were grouped with cambic horizon (Table $2 \&$ $3)$. These horizons are indicated by the symbol Bw.

\section{Soil forming processes}

Geological formations and the prevailing climatic conditions were played the decisive role in the development of soils. The soils on the quartzite-schistose landscape subjected to the process of desilication and ferritization in the prevailing humid climate conditions characterized with high rainfall and high temperature. The climatic conditions were favourable for alkaline weathering which is suitable for removal of silica and accumulation of iron and alumina oxides (Duchaufour, 1982) $^{(3)}$.

However, continuous leaching of bases in the situation of high rainfall leads to the development of moderately acidic soils.

Further, very shallow to moderately shallow on the restricted summits and low hills whereas moderately deep to very deep on high hills and in the intervening and narrow valleys with the signature eluviation and illuviation suggested topography had a role in the genesis of soils of quartzite-schistose landscape. Very shallow soils on the restricted summits and low hills were the resultant of moderate to severe erosion of surficial matter (Table 1) and their subsequent deposition on the stable landscape, manifested as deep soils in the inter-hilly valley. An increase of 1.2 times clay in the sub-surface horizons with patchy thin argillans on these landscapes indicated that these landforms were good enough to support elluvial and illuvial processes (Table 2). Thus developed illuvial sub-surface horizons hold higher nutrient, base saturation and moisture (Table $3 \& 4$ ) than overlying horizons. This suggests illuvial horizons prepared the base for arresting 
leachates of elluvial horizons, perhaps one of the reasons for supporting deep rooted plantation crops.

\section{Soil correlation}

In the present study, we have attempted to correlate the typifying pedons with the existing soil series (Harindrnath et al., 1999) ${ }^{(6)}$ based on colour, depth, surface and sub-surface texture and the sequence of diagnostic horizons.

Deep, well drained soils with clayey surface and sub-surface soils (Pedon 8) was correlated with Arukot series, other deep, moderately well drained soils with clay loam surface and clayey sub-surface (Pedon 9) were correlated with Bandoli series. Moderately deep, somewhat excessively drained soils with gravelly clay surface and sub-surface (Pedon 1) were characterized with
Darbandora series, whereas other moderately deep, moderately well drained soils, with gravelly clay loam surface and gravelly clayey surface (Pedon 2) were correlated with Gavane series. Moderately shallow, moderately well drained soils with gravelly clayey surface and sub-surface (Pedon 4) were characterized with Netravali series. Shallow, well drained soils with gravelly clayey surface and sub-surface (Pedon 5) were considered as the part of Metaveda series, other shallow, well drained soils with gravelly sandy clay surface and clayey subsurface (Pedon 3)were considered as Torse series, whereas moderately deep, moderately well drained soils with sandy loam surface and sandy clay loam to clay loam sub-surface (Pedon 9) were correlated with Pali series. Very shallow, somewhat excessively drained soils with gravelly sandy clay loam surface on the rocky sub-surface (Pedon 6) were grouped with Velge series.

Table.1 Site characteristics of pedons

\begin{tabular}{|c|c|c|c|c|c|c|}
\hline Pedon & Landform & $\begin{array}{c}\text { Slope } \\
(\%)\end{array}$ & Erosion & Drainage & $\begin{array}{c}\text { Surface } \\
\text { stoniness } \\
(\%)\end{array}$ & Present Land use \\
\hline P1 & High hill & $15-30$ & Severe & $\begin{array}{l}\text { Somewhat } \\
\text { excessively }\end{array}$ & $20-25$ & $\begin{array}{l}\text { Thin forest with } \\
\text { cashew plantation }\end{array}$ \\
\hline $\mathbf{P 2}$ & High hill & $15-30$ & Severe & Moderately & $35-40$ & $\begin{array}{l}\text { Thin forest with } \\
\text { cashew plantation }\end{array}$ \\
\hline P3 & $\begin{array}{l}\text { Restricted } \\
\text { summits }\end{array}$ & $15-30$ & Severe & Well & $15-20$ & $\begin{array}{l}\text { Forest with grass } \\
\text { land }\end{array}$ \\
\hline $\mathbf{P 4}$ & $\begin{array}{l}\text { Restricted } \\
\text { summits }\end{array}$ & $8-15$ & Moderate & Well & $40-45$ & Cashew Plantation \\
\hline P5 & Low hills & $15-30$ & Severe & Well & $35-40$ & $\begin{array}{l}\text { Forest with cashew } \\
\text { plantation }\end{array}$ \\
\hline P6 & Low hills & $8-15$ & Severe & $\begin{array}{l}\text { Somewhat } \\
\text { excessively }\end{array}$ & $40-45$ & $\begin{array}{l}\text { Forest with pasture } \\
\text { land }\end{array}$ \\
\hline P7 & $\begin{array}{l}\text { Inter-hilly } \\
\text { valley }\end{array}$ & $3-8$ & Moderate & Well & $5-10$ & $\begin{array}{l}\text { coconut, arecanut, } \\
\text { cashew }\end{array}$ \\
\hline P8 & $\begin{array}{l}\text { Inter-hilly } \\
\text { valley }\end{array}$ & $3-8$ & Slight & Well & $<5$ & $\begin{array}{l}\text { coconut, arecanut, } \\
\text { mango, oil palm }\end{array}$ \\
\hline P9 & Narrow valley & $3-8$ & Moderate & Well & $<5$ & $\begin{array}{l}\text { coconut, arecanut } \\
\text { and occasionaly } \\
\text { paddy }\end{array}$ \\
\hline
\end{tabular}


Table.2 Morphological characteristics of the soils

\begin{tabular}{|c|c|c|c|c|c|c|c|c|c|c|c|c|c|c|c|c|c|c|}
\hline \multirow[t]{2}{*}{ Horizon } & \multirow{2}{*}{$\begin{array}{c}\text { Depth } \\
\text { (cm) }\end{array}$} & \multicolumn{2}{|c|}{ Boundary } & \multicolumn{2}{|c|}{ Matrix colour } & \multirow[t]{2}{*}{ Texture } & \multirow[t]{2}{*}{ Structure } & \multicolumn{4}{|c|}{ Consistence } & \multicolumn{2}{|c|}{ Porosity } & \multicolumn{3}{|c|}{ Cutans } & \multicolumn{2}{|c|}{ Roots } \\
\hline & & $\mathrm{D}$ & $\mathrm{T}$ & $\mathrm{D}$ & M & & & $\mathrm{D}$ & M & S & $\mathrm{P}$ & $\mathrm{S}$ & Q & Ty & Th & Q & $\mathrm{S}$ & Q \\
\hline \multicolumn{19}{|c|}{ Pedon 1: Fine, mixed, isohyperthermic, Dystric Haplustepts } \\
\hline $\mathbf{A}$ & $0-10$ & $\mathrm{c}$ & $\mathrm{s}$ & 7.5YR 4/4 & $7.5 Y R 3 / 4$ & gc & $\mathrm{m} 1 \mathrm{sbk}$ & sh & $\mathrm{fr}$ & ss & ps & f & $\mathrm{m}$ & - & - & - & vf & $\mathrm{c}$ \\
\hline Bw1 & $10-33$ & $\mathrm{~g}$ & $\mathrm{~s}$ & - & 5YR 3/4 & $\mathrm{c}$ & $\mathrm{m} 2 \mathrm{sbk}$ & - & fr & ss & ps & f & $\mathrm{m}$ & - & - & - & $\mathrm{f}$ & $\mathrm{m}$ \\
\hline Bw2 & $33-58$ & $\mathrm{c}$ & $\mathrm{s}$ & - & $5 \mathrm{YR} 3 / 3$ & $\mathrm{gc}$ & $\mathrm{m} 2 \mathrm{sbk}$ & - & $\mathrm{fr}$ & $\mathrm{s}$ & $\mathrm{p}$ & $\mathrm{f}$ & $\mathrm{m}$ & - & - & - & $\mathrm{f}$ & $\mathrm{m}$ \\
\hline Bw3 & $58-80$ & $\mathrm{c}$ & $\mathrm{s}$ & - & 2.5YR 3/4 & $\mathrm{gc}$ & $\mathrm{m} 2 \mathrm{sbk}$ & - & $\mathrm{fr}$ & $\mathrm{s}$ & $\mathrm{p}$ & $\mathrm{m}$ & $\mathrm{m}$ & - & - & - & $\mathrm{m}$ & $\mathrm{m}$ \\
\hline $\mathrm{Cr}$ & $80+$ & \multicolumn{17}{|c|}{ Weathered quartzite/schistose material } \\
\hline \multicolumn{19}{|c|}{ Pedon 2: Clayey-skeletal, mixed, isohyperthermic, Dystric Haplustepts } \\
\hline Ap & $0-18$ & $\mathrm{c}$ & s & $10 Y R 4 / 4$ & $10 Y R 3 / 2$ & gcl & $\mathrm{m} 2 \mathrm{sbk}$ & sh & $\mathrm{fr}$ & s & $\mathrm{p}$ & $\mathrm{m}$ & $\mathrm{m}$ & - & - & - & $\mathrm{m}$ & f \\
\hline Bw1 & $18-35$ & $\mathrm{c}$ & s & - & $7.5 Y R 3 / 3$ & gcl & $\mathrm{m} 2 \mathrm{sbk}$ & sh & fr & s & $\mathrm{p}$ & f & $\mathrm{m}$ & - & - & - & $\mathrm{m}$ & $\mathrm{c}$ \\
\hline Bw2 & $35-56$ & $\mathrm{c}$ & w & - & 7.5YR 3/4 & $\mathrm{gc}$ & $\mathrm{m} 2 \mathrm{sbk}$ & $\mathrm{sh}$ & $\mathrm{fr}$ & $\mathrm{s}$ & $\mathrm{p}$ & $\mathrm{f}$ & $\mathrm{m}$ & - & - & - & $\mathrm{c}$ & $\mathrm{m}$ \\
\hline Bw3 & $56-90$ & $\mathrm{c}$ & w & - & $5 Y R 3 / 4$ & gc & $\mathrm{m} 2 \mathrm{sbk}$ & $\operatorname{sh}$ & $\mathrm{fr}$ & s & $\mathrm{p}$ & f & $\mathrm{m}$ & - & - & - & $\mathrm{c}$ & $\mathrm{m}$ \\
\hline $\mathrm{Cr}$ & $90+$ & \multicolumn{17}{|c|}{ Weathered quartzite/schistose material } \\
\hline \multicolumn{19}{|c|}{ Pedon 3: Clayey, mixed, isohyperthermic, Lithic Haplustepts } \\
\hline Ap & $0-17$ & $\mathrm{c}$ & s & 7.5YR 4/4 & $7.5 \mathrm{YR} 4 / 3$ & gsc & $\mathrm{m} 2 \mathrm{sbk}$ & sh & fr & ss & ps & f & $\mathrm{m}$ & - & - & - & f & $\mathrm{c}$ \\
\hline Bw & $17-35$ & $\mathrm{c}$ & w & - & $5 Y R 3 / 4$ & c & $\mathrm{m} 2 \mathrm{sbk}$ & sh & $\mathrm{fr}$ & ss & ps & f & $\mathrm{m}$ & - & - & - & f & f \\
\hline $\mathbf{R}$ & $35+$ & \multicolumn{17}{|c|}{ Hard quartzite/schistose rock } \\
\hline \multicolumn{19}{|c|}{ Pedon 4: Clayey-skeletal, mixed, isohyperthermic, Dystric Haplustepts } \\
\hline Ap & $0-20$ & $\mathrm{c}$ & s & $5 Y R 3 / 4$ & $5 Y R 3 / 3$ & gc & $\mathrm{m} 2 \mathrm{sbk}$ & sh & fr & $\mathrm{s}$ & $\mathrm{p}$ & $\mathrm{m}$ & $\mathrm{m}$ & - & - & - & $\mathrm{c}$ & $\mathrm{m}$ \\
\hline Bw1 & $20-44$ & $\mathrm{c}$ & $\mathrm{s}$ & - & 5YR 3/4 & $\mathrm{gc}$ & $\mathrm{m} 2 \mathrm{sbk}$ & sh & fr & $\mathrm{s}$ & $\mathrm{p}$ & c & $\mathrm{m}$ & - & - & - & $\mathrm{m}$ & $\mathrm{m}$ \\
\hline Bw2 & $44-73$ & $\mathrm{c}$ & w & - & $5 Y R 3 / 3$ & gc & $\mathrm{m} 2 \mathrm{sbk}$ & sh & $\mathrm{fr}$ & $\mathrm{s}$ & $\mathrm{p}$ & c & $\mathrm{m}$ & - & - & - & $\mathrm{m}$ & $\mathrm{m}$ \\
\hline $\mathrm{Cr}$ & $73+$ & \multicolumn{17}{|c|}{ Weathered quartzite/schistose material } \\
\hline \multicolumn{19}{|c|}{ Pedon 5: Clayey-skeletal, mixed, isohyperthermic, Lithic Haplustepts } \\
\hline A & $0-11$ & $\mathrm{c}$ & $\mathrm{s}$ & $2.5 \mathrm{YR} 4 / 4$ & $2.5 Y R 3 / 4$ & gc & $\mathrm{m} 1 \mathrm{sbk}$ & sh & fr & ss & $\mathrm{p}$ & vf, $\mathrm{f}$ & $\mathrm{m}$ & - & - & - & $v f, f$ & $\mathrm{~m}, \mathrm{f}$ \\
\hline
\end{tabular}




\begin{tabular}{|c|c|c|c|c|c|c|c|c|c|c|c|c|c|c|c|c|c|c|}
\hline \multirow{2}{*}{$\begin{array}{l}\text { Bw } \\
\text { R }\end{array}$} & \multirow{2}{*}{$\begin{array}{l}11-37 \\
37+\end{array}$} & a & s & - & 2.5 YR $3 / 4$ & $\mathrm{gc}$ & m1sbk & $\mathrm{sh}$ & $\mathrm{fr}$ & ss & $\mathrm{p}$ & vf & $\mathrm{m}$ & - & - & \multicolumn{2}{|c|}{ f, vf } & $c, f$ \\
\hline & & \multicolumn{17}{|c|}{ Hard quartzite/schistose rock } \\
\hline \multicolumn{19}{|c|}{ Pedon 6: Loamy-skeletal, mixed, isohyperthermic, Lithic Ustorthents } \\
\hline A & $0-12$ & c & s & & $10 Y R 3 / 3$ & gscl & $\mathrm{m} 1 \mathrm{sbk}$ & sh & fr & ss & ps & $\mathrm{f}$ & $\mathrm{m}$ & - & - & \multicolumn{2}{|l|}{$\mathrm{f}$} & f \\
\hline $\mathbf{R}$ & $12+$ & \multicolumn{17}{|c|}{ Hard quartzite/schistose rock } \\
\hline Horizon & Depth & Bo & ndary & Matri & ix colour & Texture & Structure & & & Consistenc & & & rosity & & utans & & & \\
\hline & & $\mathrm{D}$ & $\mathrm{T}$ & $\mathrm{D}$ & M & & & I & D & $\mathrm{S}$ & $\mathrm{P}$ & S & Q & Ty & Th & Q & S & Q \\
\hline Pedon 7: & ne, mixed & d, isohyl & rthern & Kanhapli & ic Haplustalfs & & & & & & & & & & & & & \\
\hline Ap & $0-16$ & a & $\mathrm{s}$ & 7.5YR 4/6 & 7.5YR 3/4 & $\mathrm{cl}$ & m2sbk & $\mathrm{s}$ & $\mathrm{h}$ & ss & ps & $\mathrm{m}$ & $\mathrm{m}$ & - & - & - & $\mathrm{m}$ & $\mathrm{m}$ \\
\hline Bt1 & $16-35$ & g & $\mathrm{s}$ & - & 5YR 3/4 & $\mathrm{cl}$ & m1sbk & 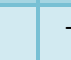 & - & ss & ps & $\mathrm{f}$ & $\mathrm{f}$ & $\mathrm{T}$ & tn & $\mathrm{p}$ & $\mathrm{c}$ & $\mathrm{c}$ \\
\hline Bt2 & $35-64$ & $\mathrm{~g}$ & $\mathrm{~s}$ & - & 5YR 3/4 & $\mathrm{c}$ & $\mathrm{m} 2 \mathrm{sbk}$ & 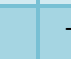 & - & $\mathrm{s}$ & $\mathrm{p}$ & $\mathrm{f}$ & $\mathrm{f}$ & $\mathrm{T}$ & tn & $\mathrm{p}$ & $\mathrm{c}$ & $\mathrm{c}$ \\
\hline Bt3 & $64-95$ & c & $\mathrm{s}$ & - & 5YR 4/6 & c & $\mathrm{m} 1 \mathrm{sbk}$ & 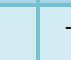 & - & $\mathrm{s}$ & $\mathrm{p}$ & $\mathrm{f}$ & $\mathrm{f}$ & $\mathrm{T}$ & tn & $\mathrm{p}$ & $\mathrm{c}$ & c \\
\hline Bt4 & $95-120$ & $\mathrm{~g}$ & $\mathrm{~s}$ & - & 7.5YR 4/6 & $\mathrm{c}$ & $\mathrm{m} 2 \mathrm{sbk}$ & 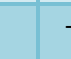 & - & $\mathrm{s}$ & $\mathrm{p}$ & - & - & $\mathrm{T}$ & tn & $\mathrm{p}$ & $\mathrm{c}$ & $\mathrm{f}$ \\
\hline Bt5 & $120-150$ & c & $\mathrm{s}$ & - & 10YR 5/6 & $\mathrm{c}$ & m1sbk & 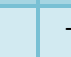 & f & $\mathrm{s}$ & $\mathrm{p}$ & - & - & $\mathrm{T}$ & tn & $\mathrm{p}$ & $\mathrm{c}$ & $\mathrm{f}$ \\
\hline Pedon 8: & ine, mixe & d, isohy & erther & ic, Kanhapli & lic Haplustalfs & & & & & & & & & & & & & \\
\hline Ap & $0-20$ & $\mathrm{a}$ & $\mathrm{s}$ & 7.5YR 4/4 & $7.5 \mathrm{YR} 4 / 3$ & $\mathrm{c}$ & m1sbk & $\mathrm{s}$ & h & $\mathrm{s}$ & $\mathrm{p}$ & $\mathrm{m}$ & $\mathrm{f}$ & - & - & - & $\mathrm{m}$ & $\mathrm{f}$ \\
\hline Bt1 & $20-53$ & $\mathrm{~g}$ & $\mathrm{~s}$ & - & 5YR 4/4 & $\mathrm{c}$ & $\mathrm{m} 2 \mathrm{sbk}$ & - & - & vs & $\mathrm{vp}$ & $\mathrm{m}$ & $\mathrm{m}$ & $\mathrm{T}$ & tn & $\mathrm{p}$ & $\mathrm{c}$ & $\mathrm{f}$ \\
\hline Bt2 & $53-75$ & $\mathrm{~g}$ & $\mathrm{~s}$ & - & $5 Y R$ 4/3 & $\mathrm{c}$ & $\mathrm{m} 2 \mathrm{sbk}$ & 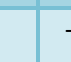 & f & vs & $\mathrm{vp}$ & $\mathrm{f}$ & $\mathrm{f}$ & $\mathrm{T}$ & tn & $\mathrm{p}$ & $\mathrm{f}$ & $\mathrm{f}$ \\
\hline Bt3 & $75-102$ & $\mathrm{~g}$ & $\mathrm{~s}$ & - & 7.5YR 3/4 & $\mathrm{c}$ & $\mathrm{m} 1 \mathrm{sbk}$ & - & f & vs & $\mathrm{vp}$ & $\mathrm{f}$ & $\mathrm{f}$ & $\mathrm{T}$ & tn & $\mathrm{p}$ & $\mathrm{f}$ & $\mathrm{f}$ \\
\hline Bt4 & $102-121$ & $\mathrm{~g}$ & $\mathrm{~s}$ & - & 7.5YR 4/4 & c & $\mathrm{m} 1 \mathrm{sbk}$ & - & - & $\mathrm{s}$ & $\mathrm{p}$ & - & - & $\mathrm{T}$ & $\operatorname{tn}$ & $\mathrm{p}$ & - & - \\
\hline Bt5 & $121-150$ & - & - & - & 7.5YR 4/4 & c & m1sbk & 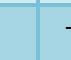 & - & $\mathrm{s}$ & $\mathrm{p}$ & - & - & $\mathrm{T}$ & tn & $\mathrm{p}$ & - & - \\
\hline Pedon 9: & li series: & : Fine-lo & $\mathbf{y}, \mathrm{m}$ & , isohyper & rthermic, Dys & c Haplus & stepts & & & & & & & & & & & \\
\hline Ap & $0-18$ & c & $\mathbf{s}$ & 10YR 6/6 & 10YR 4/4 & scl & m2sbk & $\mathbf{s}$ & h & $\mathbf{s}$ & $\mathbf{p}$ & f & $\mathbf{m}$ & - & - & - & f & c \\
\hline Bw1 & $18-40$ & $\mathrm{c}$ & $\mathrm{s}$ & - & 10YR 4/6 & $\mathrm{scl}$ & $\mathrm{m} 2 \mathrm{sbk}$ & $\mathrm{s}$ & h & $\mathrm{s}$ & $\mathrm{p}$ & f & $\mathrm{m}$ & - & - & - & $\mathrm{f}$ & $\mathrm{f}$ \\
\hline Bw2 & $40-78$ & $\mathrm{c}$ & $\mathrm{w}$ & - & 7.5YR 4/6 & $\mathrm{cl}$ & $\mathrm{m} 2 \mathrm{sbk}$ & $\mathrm{s}$ & h & $\mathrm{s}$ & $\mathrm{p}$ & $\mathrm{f}$ & $\mathrm{m}$ & - & - & - & - & - \\
\hline $\mathbf{R}$ & $78+$ & Har & $\operatorname{artzi}$ & histose ro & & & & & & & & & & & & & & \\
\hline
\end{tabular}


Table.3 Physical characteristics of the soils

\begin{tabular}{|c|c|c|c|c|c|c|c|c|}
\hline \multirow[t]{2}{*}{ Horizon } & \multirow[t]{2}{*}{ Depth (cm) } & $\begin{array}{l}\text { Coarse } \\
\text { Fragments } \\
(>\mathbf{2 . 0} \mathbf{~ m m})\end{array}$ & $\begin{array}{c}\text { Sand } \\
(2.0-0.05)\end{array}$ & $\begin{array}{c}\text { Silt } \\
(0.05-0.002)\end{array}$ & $\underset{(<0.002)}{\text { Clay }}$ & \multirow{2}{*}{$\begin{array}{c}\begin{array}{c}\text { Bulk } \\
\text { density }\end{array} \\
\left(\mathrm{Mg} \mathrm{m}^{-3}\right)\end{array}$} & \multirow{2}{*}{$\begin{array}{r}\text { AWC } \\
(\%)\end{array}$} & \multirow{2}{*}{$\begin{array}{l}\text { AWC } \\
\left(\mathrm{cm} \mathrm{m}^{-1}\right)\end{array}$} \\
\hline & & \multicolumn{4}{|c|}{$(\%)$} & & & \\
\hline \multicolumn{9}{|c|}{ Pedon 1: Fine-loamy, Dystric Haplustepts } \\
\hline $\mathbf{A}$ & $0-10$ & 25 & 29.6 & 22.2 & 48.2 & 1.38 & 8.6 & \multirow[t]{4}{*}{11.2} \\
\hline Bw1 & $10-33$ & 10 & 18.3 & 25.2 & 56.4 & 1.40 & 9.4 & \\
\hline Bw2 & $33-58$ & 20 & 16.5 & 23.7 & 59.8 & 1.43 & 9.9 & \\
\hline Bw3 & $58-80$ & 25 & 19.2 & 18.4 & 62.3 & 1.46 & 10.8 & \\
\hline $\mathbf{C r}$ & $80+$ & \multicolumn{7}{|c|}{ Weathered quartzite-schistose material } \\
\hline \multicolumn{9}{|c|}{ Pedon 2: Clayey-skeletal, DystricHaplustepts } \\
\hline Ap & $0-18$ & 35 & 37.4 & 33.2 & 29.4 & 1.30 & 9.2 & \multirow[t]{4}{*}{11.6} \\
\hline Bw1 & $18-35$ & 45 & 42.4 & 28.2 & 29.4 & 1.32 & 8.8 & \\
\hline Bw2 & $35-56$ & 40 & 31.4 & 28.2 & 40.4 & 1.36 & 9.4 & \\
\hline Bw3 & $56-90$ & 50 & 40.6 & 8.2 & 51.2 & 1.40 & 10.0 & \\
\hline $\mathrm{Cr}$ & $90+$ & \multicolumn{7}{|c|}{ Weathered quartzite-schistose material } \\
\hline \multicolumn{9}{|c|}{ Pedon3:Clayey, Lithic Haplustepts } \\
\hline $\mathbf{A}$ & $0-17$ & 20 & 45.6 & 17.7 & 36.7 & 1.43 & 9.7 & \multirow[t]{2}{*}{5.2} \\
\hline Bw & $17-35$ & - & 40.6 & 18.2 & 41.2 & 1.45 & 10.8 & \\
\hline $\mathbf{R}$ & $35+$ & \multicolumn{7}{|l|}{ Hard quartzite rock } \\
\hline \multicolumn{9}{|c|}{ Pedon 4: Clayey-skeletal, Dystric Haplustepts } \\
\hline Ap & $0-20$ & 35 & 20.8 & 32.9 & 46.3 & 1.42 & 9.5 & \multirow{3}{*}{10.7} \\
\hline Bw1 & $20-44$ & 40 & 14.6 & 37.9 & 47.5 & 1.43 & 9.9 & \\
\hline Bw2 & $44-73$ & 45 & 12.5 & 37.8 & 49.7 & 1.45 & 11.0 & \\
\hline $\mathbf{C r}$ & $73+$ & \multicolumn{7}{|c|}{ Weathered quartzite-schistose material } \\
\hline \multicolumn{9}{|c|}{ Pedon 5:Clayey-skeletal, Lithic Haplustepts } \\
\hline $\mathbf{A}$ & $0-11$ & 40 & 44.4 & 9.4 & 46.2 & 1.47 & 8.4 & 4.9 \\
\hline Bw & $11-37$ & 45 & 43.6 & 9.2 & 47.2 & 1.48 & 9.1 & \\
\hline $\mathbf{R}$ & $37+$ & Hard quartzite rocl & & & & & & \\
\hline Pedon 6: & oamy-skeletal, & thic Ustorthents & & & & & & \\
\hline $\mathbf{A}$ & $0-12$ & 45 & 48.7 & 21.9 & 29.4 & 1.32 & 8.9 & 1.4 \\
\hline $\mathbf{R}$ & $12+$ & Hard quartzite rocl & & & & & & \\
\hline Pedon 7:1 & ne, Kanhaplic & lustalfs & & & & & & \\
\hline Ap & $0-16$ & 5 & 35.8 & 31.4 & 32.8 & 1.35 & 8.5 & 13.4 \\
\hline Bt1 & $16-35$ & 5 & 37.6 & 31.1 & 31.3 & 1.37 & 8.1 & \\
\hline Bt2 & $35-64$ & 5 & 35.0 & 24.8 & 40.2 & 1.40 & 10.5 & \\
\hline Bt3 & $64-95$ & 10 & 36.2 & 23.8 & 40.0 & 1.43 & 10.0 & \\
\hline Bt4 & $95-120$ & 10 & 33.5 & 25.9 & 40.6 & 1.42 & 10.8 & \\
\hline Bt5 & $120-150$ & 10 & 39.7 & 20.2 & 40.2 & 1.44 & 10.2 & \\
\hline Pedon 8: & ine, Kanhaplic & aplustalfs & & & & & & \\
\hline Ap & $0-20$ & 5 & 18.7 & 32.2 & 49.2 & 1.34 & 10.3 & 14.0 \\
\hline Bt1 & $20-53$ & 3 & 28.3 & 24.6 & 47.1 & 1.36 & 9.7 & \\
\hline Bt2 & $53-75$ & 2 & 19.9 & 32.7 & 47.4 & 1.37 & 9.9 & \\
\hline Bt3 & $75-102$ & - & 8.9 & 35.9 & 55.2 & 1.40 & 11.1 & \\
\hline Bt4 & $102-121$ & - & 9.3 & 35.2 & 55.5 & 1.42 & 11.2 & \\
\hline Bt5 & $121-150$ & - & 8.8 & 35.4 & 55.8 & 1.43 & 11.3 & \\
\hline Pedon 9: & ine-loamy, Dys & c Haplustepts & & & & & & \\
\hline Ap & $0-18$ & - & 68.5 & 10.7 & 20.8 & 1.36 & 7.5 & 9.4 \\
\hline Bw1 & $18-40$ & - & 47.8 & 21.8 & 30.4 & 1.38 & 8.6 & \\
\hline Bw2 & $40-78$ & - & 40.6 & 26.2 & 33.2 & 1.40 & 9.3 & \\
\hline $\mathbf{R}$ & $78+$ & Hard quartzite-schi & & & & & & \\
\hline WM-(Sur & ace) & 23.3 & 38.8 & 23.5 & 37.7 & 1.40 & 9.0 & \\
\hline WM-(Sul & urface) & 22.9 & 33.1 & 23.3 & 43.6 & 1.40 & 9.8 & \\
\hline
\end{tabular}


Table.4 Chemical characteristics of the soils

\begin{tabular}{|c|c|c|c|c|c|c|c|c|c|c|c|c|c|}
\hline \multirow{2}{*}{$\begin{array}{l}\text { Hori- } \\
\text { zon }\end{array}$} & \multirow{2}{*}{$\begin{array}{l}\text { Depth } \\
\text { (cm) }\end{array}$} & \multicolumn{2}{|c|}{ pH (1:2.5) } & \multirow{2}{*}{$\begin{array}{c}\text { EC } \\
(1: 2.5) \\
\left(\mathbf{d S ~ m}^{-1}\right)\end{array}$} & \multirow{2}{*}{$\begin{array}{l}\text { OC } \\
(\%)\end{array}$} & \multicolumn{4}{|c|}{ Exchangeable bases } & \multirow[t]{3}{*}{ CEC } & \multirow{3}{*}{$\begin{array}{c}\text { BS } \\
1 N \\
\mathrm{NH}_{4} \mathrm{O} \\
\mathrm{Ac} \\
(\%)\end{array}$} & \multicolumn{2}{|c|}{ Acidity } \\
\hline & & $\mathrm{H}_{2} \mathrm{O}$ & $\begin{array}{c}1 N \\
\mathrm{KCl}\end{array}$ & & & $\mathrm{Ca}^{2+}$ & $\mathrm{Mg}^{2+}$ & $\mathrm{Na}^{+}$ & $\mathrm{K}^{+}$ & & & Ex. H & Ex. Al \\
\hline \multicolumn{9}{|c|}{ Pedon 1: Fine-loamy, Dystric Haplustepts } & & & & $\operatorname{cmol}\left(\mathrm{p}^{+}\right) \mathrm{kg}^{-1}$ & \\
\hline A & $0-10$ & 5.9 & 4.6 & 0.03 & 3.3 & 3.57 & 0.26 & 0.67 & 0.22 & 18.4 & 25.6 & 0.14 & 0.07 \\
\hline Bw1 & $10-33$ & 5.8 & 4.4 & 0.03 & 2.5 & 3.48 & 0.31 & 0.29 & 0.15 & 17.8 & 23.7 & 0.15 & 0.27 \\
\hline Bw2 & $33-58$ & 5.7 & 4.3 & 0.02 & 1.8 & 2.98 & 0.27 & 0.23 & 0.13 & 14.6 & 24.8 & 0.18 & 0.35 \\
\hline Bw3 & $58-80$ & 5.7 & 4.3 & 0.02 & 1.5 & 3.38 & 0.23 & 0.25 & 0.11 & 14.7 & 27.0 & 0.19 & 0.36 \\
\hline $\mathrm{Cr}$ & $80+$ & \multicolumn{12}{|c|}{ Weathered quartzite-schistose material } \\
\hline \multicolumn{14}{|c|}{ Pedon 2: Clayey-skeletal, DystricHaplustepts } \\
\hline Ap & $0-18$ & 5.7 & 4.5 & 0.04 & 4.0 & 3.18 & 1.52 & 0.20 & 0.13 & 10.2 & 49.3 & 0.06 & 0.01 \\
\hline Bw1 & $18-35$ & 5.9 & 4.8 & 0.02 & 3.0 & 3.30 & 1.47 & 0.18 & 0.12 & 11.2 & 45.3 & 0.08 & 0.04 \\
\hline Bw2 & $35-56$ & 5.8 & 4.6 & 0.02 & 2.6 & 3.70 & 1.48 & 0.18 & 0.12 & 13.7 & 40.0 & 0.10 & 0.02 \\
\hline Bw3 & $56-90$ & 5.9 & 4.7 & 0.02 & 1.8 & 4.30 & 1.46 & 0.17 & 0.11 & 13.9 & 43.5 & 0.09 & 0.01 \\
\hline $\mathrm{Cr}$ & $90+$ & \multicolumn{12}{|c|}{ Weathered quartzite-schistose material } \\
\hline Pedon & 3: Clayey, L & ic Наa & ustept & & & & & & & & & & \\
\hline A & $0-17$ & 5.8 & 4.4 & 0.04 & 3.3 & 3.67 & 1.13 & 0.23 & 0.14 & 15.4 & 33.6 & 0.12 & 0.40 \\
\hline Bw & $17-35$ & 5.9 & 4.6 & 0.05 & 2.0 & 3.42 & 0.96 & 0.18 & 0.11 & 14.7 & 31.8 & 0.10 & 0.30 \\
\hline $\mathbf{R}$ & $35+$ & Hard & uartzite & chistose $r$ & & & & & & & & & \\
\hline Pedon & 4:Clayey & tal, Dy & tric $\mathbf{H}$ & lustepts & & & & & & & & & \\
\hline Ap & $0-20$ & 6.0 & 5.1 & 0.04 & 3.6 & 2.04 & 1.16 & 0.22 & 0.24 & 14.8 & 24.7 & 0.03 & 0.02 \\
\hline Bw1 & $20-44$ & 6.1 & 5.3 & 0.03 & 2.6 & 1.87 & 1.30 & 0.21 & 0.22 & 15.8 & 22.8 & 0.02 & 0.01 \\
\hline Bw2 & $44-73$ & 6.1 & 5.3 & 0.03 & 1.7 & 2.02 & 1.25 & 0.20 & 0.20 & 16.8 & 21.8 & 0.02 & 0.01 \\
\hline $\mathrm{Cr}$ & $73+$ & Weatl & ered qu & tzite-schis & se mate & & & & & & & & \\
\hline Pedon & 5: Clay & etal, L & hic Ha & ustepts & & & & & & & & & \\
\hline A & $0-11$ & 5.5 & 4.5 & 0.09 & 2.5 & 2.23 & 1.12 & 0.14 & 0.26 & 14.3 & 26.2 & 0.09 & 0.20 \\
\hline Bw & $11-37$ & 5.7 & 4.6 & 0.03 & 1.4 & 2.40 & 1.20 & 0.17 & 0.16 & 12.2 & 32.2 & 0.08 & 0.13 \\
\hline $\mathbf{R}$ & $37+$ & Hard & uartzite & schistose $r$ & & & & & & & & & \\
\hline Pedon & 6: Loamy-sk & etal, L & hic Us & orthents & & & & & & & & & \\
\hline $\mathbf{A}$ & $0-12$ & 5.8 & 4.7 & 0.02 & 3.1 & 1.02 & 0.32 & 0.2 & 0.14 & 8.7 & 19.3 & 0.07 & 0.13 \\
\hline $\mathbf{R}$ & $12+$ & Hard & uartzi & schistose & terial & & & & & & & & \\
\hline Pedo & 7: Fine & p,lic & plusta & & & & & & & & & & \\
\hline Ap & $0-16$ & 5.3 & 4.6 & 0.23 & 0.5 & 5.25 & 1.42 & 0.05 & 0.15 & 15.4 & 44.6 & 0.04 & 0.06 \\
\hline Bt1 & $16-35$ & 5.8 & 4.8 & 0.11 & 1.4 & 5.48 & 1.63 & 0.02 & 0.12 & 15.8 & 45.8 & 0.06 & 0.05 \\
\hline Bt2 & $35-64$ & 5.7 & 4.4 & 0.03 & 0.5 & 2.23 & 0.93 & 0.04 & 0.12 & 9.0 & 37.0 & 0.05 & 0.04 \\
\hline Bt3 & $64-95$ & 5.9 & 4.6 & 0.02 & 0.2 & 2.20 & 0.75 & 0.06 & 0.07 & 9.0 & 34.4 & 0.03 & 0.09 \\
\hline Bt4 & $95-120$ & 6.1 & 4.9 & 0.03 & 0.2 & 2.22 & 0.93 & 0.07 & 0.05 & 8.1 & 40.3 & 0.04 & 0.03 \\
\hline Bt5 & $120-150$ & 6.0 & 5.0 & 0.02 & 0.1 & 1.97 & 0.90 & 0.06 & 0.04 & 7.8 & 37.9 & 0.04 & 0.02 \\
\hline Pedo & 8: Fine, & plic H & plusta & & & & & & & & & & \\
\hline Ap & $0-20$ & 6.4 & 5.9 & 0.05 & 3.4 & 6.41 & 2.26 & 0.07 & 0.46 & 15.7 & 58.7 & 0.02 & 0.00 \\
\hline Bt1 & $20-53$ & 6.1 & 5.6 & 0.04 & 1.7 & 5.86 & 2.48 & 0.08 & 0.18 & 14.1 & 60.8 & 0.05 & 0.00 \\
\hline Bt2 & $53-75$ & 6.5 & 5.7 & 0.03 & 1.0 & 4.91 & 2.78 & 0.08 & 0.13 & 14.8 & 53.2 & 0.05 & 0.00 \\
\hline Bt3 & $75-102$ & 6.5 & 5.7 & 0.03 & 0.8 & 5.24 & 3.00 & 0.09 & 0.12 & 14.1 & 59.8 & 0.05 & 0.00 \\
\hline Bt4 & $102-121$ & 6.3 & 5.8 & 0.03 & 0.6 & 5.03 & 2.60 & 0.07 & 0.12 & 12.3 & 63.5 & 0.05 & 0.00 \\
\hline Bt5 & $121-150$ & 6.2 & 5.6 & 0.03 & 0.4 & 5.01 & 2.58 & 0.08 & 0.12 & 12.3 & 63.4 & 0.05 & 0.00 \\
\hline Pedon & : Fine-loan & Dystr & Hapl & tepts & & & & & & & & & \\
\hline Ap & $0-18$ & 5.8 & 4.8 & 0.11 & 2.3 & 0.92 & 0.41 & 0.11 & 0.05 & 5.5 & 27.1 & 0.18 & 0.48 \\
\hline Bw1 & $18-40$ & 6.0 & 5.2 & 0.03 & 1.5 & 1.20 & 0.47 & 0.13 & 0.04 & 5.9 & 31.2 & 0.16 & 0.45 \\
\hline Bw2 & $40-78$ & 6.1 & 5.3 & 0.03 & 0.8 & 1.46 & 0.58 & 0.12 & 0.04 & 6.7 & 32.8 & 0.13 & 0.40 \\
\hline $\mathbf{R}$ & $78+$ & Hard & uartzite & histose & & & & & & & & & \\
\hline WN & rface) & 5.8 & 4.8 & 0.07 & 2.9 & 3.14 & 1.07 & 0.21 & 0.20 & 13.2 & 34.3 & 0.08 & 0.15 \\
\hline WM- & ubsurface) & 5.9 & 4.9 & 0.03 & 1.7 & 2.80 & 1.08 & 0.16 & 0.12 & 12.3 & 33.8 & 0.09 & 0.15 \\
\hline
\end{tabular}




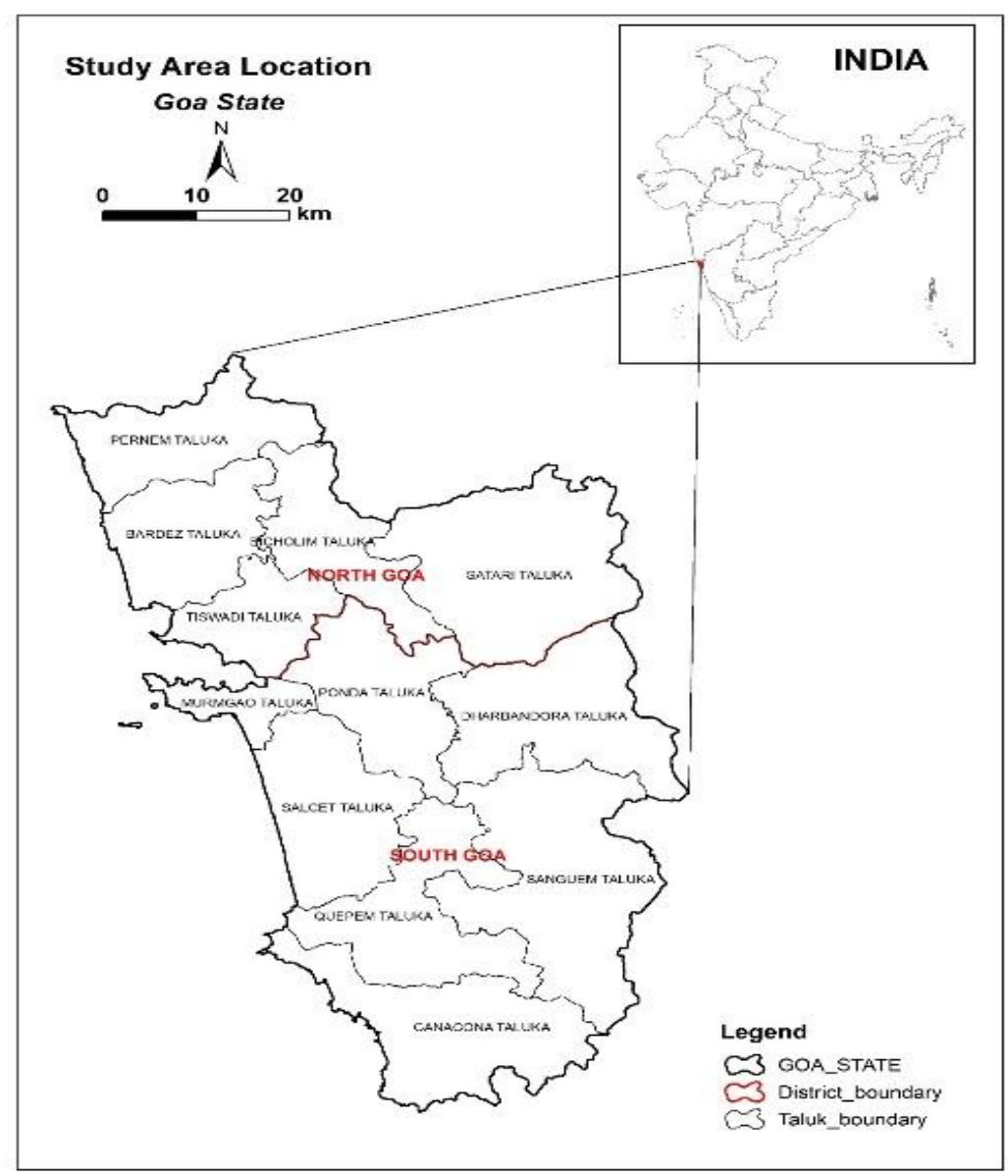

Fig.1 Location of the study area

\section{Soil classification}

Based on the morphological, physical and chemical properties, the typifying pedons were classified according to soil taxonomy (Soil Survey Staff 2006) $^{(20)}$ into the order Entisols, Inceptisols and Alfisols. Soils of Pedon 1 were classified as members of Fine, mixed hyperthermic family of Dystric Haplustepts of Inceptisol soil order accounting base saturation $<60$ per cent with clayey soil texture in the control section and soil depth more than $50 \mathrm{~cm}$. The soils of Pedon 2 and 4 were differ from Pedon 1 with respect to gravel content. These were classified as members of clayey-skeletal mixed iso-hyperthemic family of Dystric Haplustepts in Inceptisols soil orders. Pedon 3 and 5 were differ with Pedon 1 in respect to both gravel content and depth (less than 50 $\mathrm{cm}$ ) were classified as members of clayeyskeletal mixed iso-hyperthemic family of Lithic Haplustepts in Inceptisols soil orders.

The soils of Pedon 6 were classified as loamy-skeletal mixed isohyperthermic family of Lithic Ustorthents sub-group of Entisol soil order in absence of pedogenic signature. Further Pedon 7 and 8 were classified as member of fine, mixed hyperthermic family of Typic Haplustalfs accounting argillic horizon and base saturation of more than 35 per cent. Soils of Pedon 9 were grouped as member of fine loamy, mixed, isohyperthermic family of Dystric Haplustepts sub-group of Inceptisol soil order. 
Int.J.Curr.Microbiol.App.Sci (2020) 9(6): 228-241

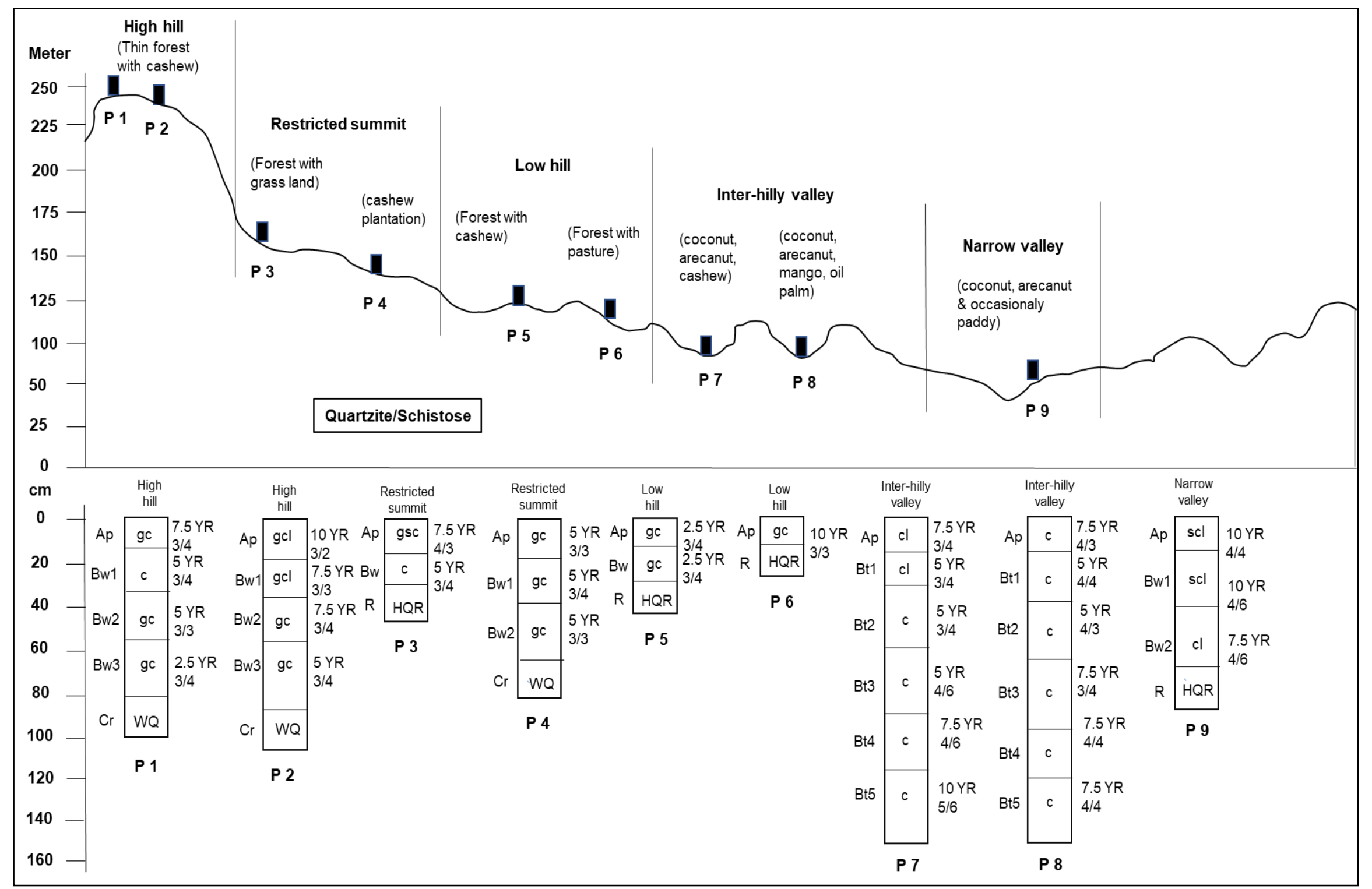

Fig.2 Soils on quartzite-schistose landscape 
Based on the results, it is concluded that the soils of quartzite-schistose in tropical region of Goa in a topo-sequence were very shallow to deep, slightly to moderately acidic in rection, medium to high in organic carbon content, low in CEC and exchange complex was dominated by $\mathrm{Ca}^{2+}$ followed by $\mathrm{Mg}^{2+}$, $\mathrm{Na}^{+}$and $\mathrm{K}^{+}$ions in general.

The soils were classified as Lithic Ustorthents, Lithic Haplustepts, Dystric Haplustepts, Typic Haplustalfs. Further the soil depth and landform relationship hold good from restricted summit to the narrow valley on quartzite-schistose lanscape.

\section{References}

1. Anil Kumar KS, Nair KM, and Gaddi AV. Characterization of soils of Talaulim watershed, North Goa and their suitability for cashew production. Journal of Plantation Crops. 2011; 39(3):363-369.

2. Diwakar DPS. Studies on some heavy soils of different origin of Bihar with special references of their genesis, characterization and classification. A Ph.D. Thesis, RAU, Pusa, Bihar. 2005; 40:496-504.

3. Duchaufour P. Pedology, pedogenesis andclassification (Translated by T.R. Paton), George Allen \&Unwin (Publishers) Ltd. 40, Museum Street Lond., WCIAILU, U.K. 1982.

4. Garhwal RS, Qureshi FM,Giri JD. Characterization and classification of the soils of Sirohi district of Rajasthan. Agropedology. 2013; 23(1):8-15.

5. Govindarajan SV, Murthy RS, Jain SP, Raghu Mohan NG, Venkatraman NA. Survey of natural resources of Goa with particular reference to soil and land classification or agricultural development. ICAR Tech. Bull. No. 49, Indian Council of Agricultural Research, New Delhi. 1974; 49 p + map 14 sheets.
6. Harindranath CS, Venugopal KR,. Raghumohan NG, Sehgal J, Velayutham M. Soils of Goa for optimizing land use. NBSS Publ. 74b (Soils of India series) National Bureau of Soil Survey and Land Use Planning, Nagpur, India. 1999; 131 pp+2 sheets of soil map on 1:500000 scale.

7. Jackson ML. Soil Chemical Analysis, Prentice Hall India limited, New Delhi. 1973

8. James A Thompson, James CB. Colour index for identifying hydric conditions for seasonally saturated mollisols in Minnesota. Soil Science Society of America. Journal. 1996; 60:1979-1988.

9. Manchanda ML, Kudrat M, Tiwari AK. Soil survey and mapping using remote sensing. Tropical Ecology. 2002; 43: 6174.

10. Mandal DK, Mandal C, Singh SK. AgroEcological Regions of India (Revised). NBSS\&LUP Publ. No. 170, ICARNBSS\&LUP, Nagpur, India. 2016; 89 p.

11. Murthy RS, Hirekeru LR, Deshpande SB, Venkat Rao BV. (eds.).Benchmark soils of India: Morphology, characteristics and classification for resource management. NSSS Publ. 1982, 374p.

12. Sarkar D, Gangopadhyay SK, Velayuthum M. Soil toposequence relationship and classification in lower outlier of Chhotanagpur plateau. Agropedology.2001; 11: 29-36.

13. Sehgal JL, Pedology: Concepts and Applications, Kalyani Publishers, New Delhi. 1996, 287p.

14. Sehgal JL, Mandal DK. Soil temperature regimes of India. NBSS Publ. 41, NBSS\&LUP (ICAR), Nagpur, Maharashtra. 1994.

15. Sharma PD. Soil science research - vision 2025. Indian Society of Soil Science News Letter 20. 2006; p.1.

16. Sharma RC, Mandal AK, Saxena RK, Verma KS. Characterization, formation 
and reclamability of sodic soils under different geomorphic plains of Ganga basin. Extentended Summery, International Conference on Sustainable Management of Sodic Lands, Feb 94,2004, Luckhnow, India Vol. I. 1999; pp168-170.

17. Singh SK, Shyampura RL, Singh RS, Harindranath CS, Venugopal KR. Genesis of some soils of Goa, Journal of the Indian Society of Soil Science. 1998;46(4):651656.

18. Sireesha PVG, Naidu MVS. Studied on genesis, characterization and classification of soils in semi-arid Agro-ecological region: A case study in Banaganapalle mandal of Kurnool district, Andhra Pradesh. Journal of the Indian Society of Soil Science. 2013; 61:167-178.

19. Soil Survey Division Staff. Soil Survey Manual, Handbook No.18, USDA, Washington, D.C. 2000

20. Soil Survey Staff. Keys to Soil Taxonomy, United State Department of
Agriculture (USDA), NRCS, $10^{\text {th }}$ edition. 2006; $332 \mathrm{p}$.

21. Thangasamy A, Naidu MVS, Ramavtharam N, Raghava Reddy C. Characterization, classification and evaluation of soil resources in Sivagiri micro-watershed of Chittoor district in Andhra Pradesh for sustainable land use planning. Journal of the Indian Society of Soil Science. 2005; 53:11-21.

22. Tripathi D, Verma JR, Patil KS, Singh K.. Characteristics, classification and suitability of soils for major crops of Kiar Nagali micro-watershed in North-West Himalayas. Journal of the Indian Society of Soil Science. 2006;54(2):131-136.

23. Vara Prasad Rao AP, Naidu MVS, Ramavatharam N, Rama Rao G. Characterization, classification and evaluation of soils on different landforms in Ramachandrapuram mandal of Chittoor district in Andhra Pradesh for sustainable land use planning. Journal of the Indian Society of Soil Science. 2008; 56:23-33.

\section{How to cite this article:}

Mohekar. D. S., S. K. Singh, S. Chattaraj, V. Ramamurthy and Srivastava. R. 2020. Characterization and Classification of Soils on Quartzite-Schistose Landscape in Tropical Ecosystem of Goa-in a Topo-sequence. Int.J.Curr.Microbiol.App.Sci. 9(06): 228-241. doi: https://doi.org/10.20546/ijcmas.2020.906.029 